\title{
E-business challenges in the field of payment solutions - Bitcoin a sustainable currency or gambling
}

\author{
Jacek Binda ${ }^{1}$ \\ ${ }^{1}$ Department of Finance and Information Technologies, Bielsko-Biała School of Finance and Law \\ ul. Tańskiego 5, 43-382 Bielsko-Biała - Poland
}

\begin{abstract}
Money is a widely accepted commodity allowing to determine the economic value of purchased goods and services and to make payments. Over the centuries, "money" has been constantly evolving. In recent times, following dynamic development of various forms of e-business, dematerialized money has emerged. However, in constantly changing conditions it is very difficult to grasp the essence of the so called e-money or cryptocurrencies. The paper tries to define Bitcoin, one of the most recognizable cryptocurrencies, and answer the question whether investing in cryptocurrencies is a serious business or a mere gambling. In search for the answers, the author reviews literature on the topic and conducts his own risk analysis based on Value at Risk measure, of selected traditional currencies and Bitcoin. The results of the analysis unambiguously show that investments in Bitcoin are burdened with definitely much higher risk. Furthermore, conclusions of the considerations clearly show that despite growing popularity of cryptocurrencies they do not fulfill the definition of both electronic money or money in general. The paper attempts to discuss selected issues related to Bitcoin cryptocurrencies from the monetary point of view but also with respect to restrictions of Bitcoin as a means of payment, investments in Bitcoin and risk assessment.
\end{abstract}

Index Terms- Cryptocurrencies, Bitcoin, Trading market, Electronic money

\section{INTRODUCTION}

The end of the 20th century was a period of sudden transformations. Now this period is referred to as 'the postindustrial revolution' or 'information revolution'. The strategic elements of the new order are: information management (IM) and knowledge management (KM). The processes of convergence of teleinformation technologies and electronic media systems started to dominate and became significant attributes of the new economic phenomenon known as the netbased economy. The style of communication between market

ASEJ - Scientific Journal of Bielsko-Biala School of
Finance and Law
Volume 22, No 3 (2018), 8 pages
DOI: $10.5604 / 01.3001 .0012 .7280$

Received 03 September 2018; Accepted 17 September 2018 participants was also transformed. It was the catalyst of dynamic changes leading to technical convergence of products and their markets as well as to liberalization of the electronic market (also electronic banking services). In the new reality money has lost its material form and the newly emerged, dematerialised forms of payment are increasingly present on the markets. In the era of dynamic development of new technologies and forced changes in the functioning of markets, the importance of electronic money i.e. electronic impulses or bit strings, takes on meaning. However, interpretation problems concerning cryptocurrencies do exist due to their conceptual complexity both in the legal and economic sense.

\section{THE ROLE OF ICT TECHNOLOGIES IN DEVELOPMENT OF E-BUSINESS SERVICES}

Past centuries witnessed various transformation periods e.g. the Renaissance - the Enlightenment. Later periods of dynamic changes brought about advancements in science and information technologies. These changes have had a considerable impact on our civilization. Technological boom, which can be witnessed for some time now, is a resultant of development tendencies within equipment, software and means of communication. We live in a global information village, we travel on the information highway, we are the information society.

The rise of economy communicated with the net is closely related to the possibilities of ICT technologies and to the degree of their uptake what allows for effective consumption or the so called network effect. The dynamics of changes as well as strong competition between teleinformation companies for stable competitive advantage have led to the creation of a wide spectrum of services. The processes are accompanied by emergence of new segments and the loss of importance of existing ones. Electronic transactions on the world stock

Regular research paper: Published 15 October 2018

Corresponding author's e-mail: jbinda@wsfip.edu.pl

Copyright $(C) 2018$ This is an open access article distributed under the Creative Commons Attribution CC-BY-NC 4.0 License. 
markets produce the domino effect - the reactions of stock markets resulting from their respective behavior are only delayed due to different time zones. These examples show how considerable is the impact of information technologies on all layers of life, all over the globe. Technological progress is the driving force behind the development of information society, it transforms almost all aspects of people's existence.

The pace of growth of modern technologies carries a number of challenges and dilemmas for business environment, mainly with respect to the management styles. The world of business dictates the speed to the information revolution in management because it uses state-of-the-art solutions in which knowledge is a tool of strategic importance. New telecommunication technologies, which are the catalyst for changes in e-business, play essential role with respect to:

- combining design, production, supply, sales, administration, technical services of companies which allows for creation of organizations integrated electronically,

- electronic surveillance systems leading to improvements such as cost-effectiveness or labor efficiency,

- combining networks of suppliers, materials and spare parts or companies and manufacturers, wholesalers and retailers, which generates savings with respect to storage on each phase of production, distribution and allows for prompt reaction to day-by-day changes in the demand for goods or services,

- greater flexibility within development and production of new models of goods, which is sometimes defined as the 'economy of scale'.

Dynamic development of new technologies considerably influences the structure of the economy (emergence of new sectors of industry and services), internal structure of organizations, management style and types of ties between companies. There are tendencies towards horizontal linking of design, production and marketing in contrast to the Taylor's system of vertical and hierarchical control. The flow of information inside and outside the company becomes more uninhibited and new channels of communication are born.

Taking the above into account, it can be said that the economy has changed more in the last decade alone than in the previous five decades. The pioneers of these changes were businesses who first spotted the opportunities in ICT technologies. In 1999 American companies invested in teleinformation technologies the amounts equal to $5 \%$ of GDP. However, the financial crisis that came later slashed the forecasts for 2009 IT investments from 4.2\% GDP to about $0.9 \%$ GDP. A considerable part of investment plans was cancelled; another part was postponed (especially in Europe) due to the dollar exchange rate. Gartner Group, a British research center, published a study which argued that in the first quarter of 2009 about $42 \%$ of companies reduced their budget on maintenance and development of IT environments as compared to 2008. The recovery in IT expenditure could be observed in the period 2012-2014. However, in 2015 the figures were corrected and the total expenditure on IT projects amounted to only 3.5 billion dollars. The expenditure was $5.5 \%$ lower than in 2014, this was caused by strengthening dollar, Figure 1.

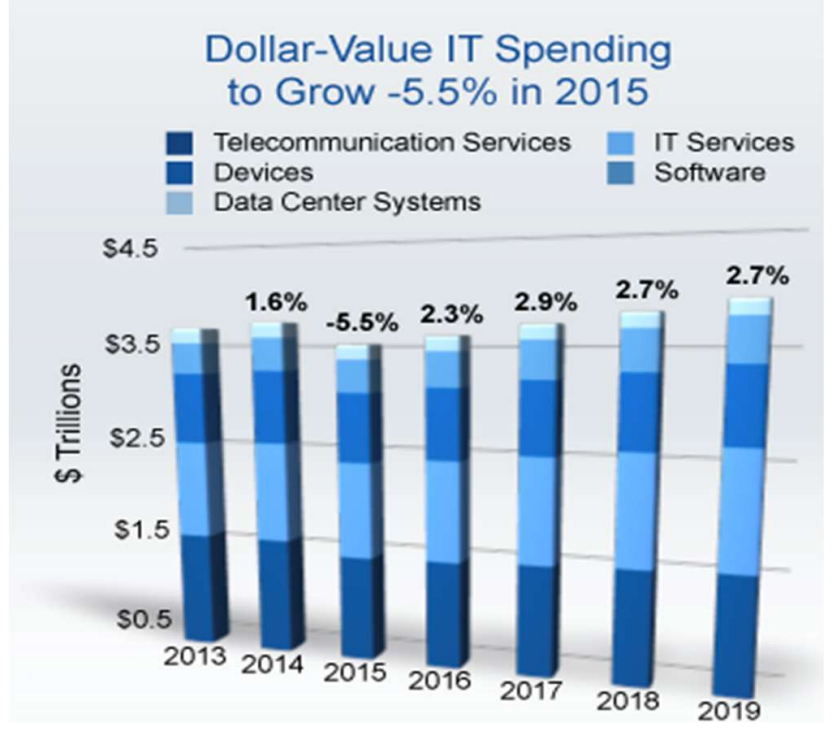

FIGURE 1. IT EXPENDITURE SOURCE: OWN WORK BASED ON FORECAST ALERT: IT SPENDING, WORLDWIDE, 2Q15 UPDATE. GARTNER, INC. AND/OR ITS AFFILIATES, GARTNER, INC. AND/OR ITS AFFILIATES, 2015

The dynamics of growth of the IT sector in the long perspective depends on the global economic situation and on the way the IT tools are used. According to the OECD experts, the increase in investment in IT will be triggered by the growth in interest in special business applications, modern and highly specialized communication systems and IT outsourcing services. The factors determining the shape of this sector are offshoring [a shift of certain business processes (production and services) to another country in order to cut costs] and outsourcing [some parts of an organisation are extracted from its structure and their functions are passed on to external entities to take care of] of selected business processes. Their share market is translated into development of local teleinformation sector. The main providers of IT offshoring services are Central-Eastern Europe countries. IT departments of companies have, thus, the choice of services rendered by local or foreign providers whenever they have to put in practice their corporate strategic development plans. The previously predominant concern about high costs of development of new IT solutions has been replaced by deep confidence that IT functions equip the services with considerable added value. ICT tools are currently widely used in business, they facilitate the way companies communicate with each other, help improve processes and build competitive market position.

The methods of financial settlements are also under dynamic transformation. This is reflected in the rise of the number of instruments available to non-cash transactions, number of payment cards, number of retailers accepting credit cards, number of cashless transactions with the use of electronic money or cryptocurrencies. Regardless of the type of non-cash payment instruments (card payments, electronic money, cryptocurrencies), the mere fact of their use in payment turnover is of significant importance for reducing the costs of cash transactions. It is estimated that this cost is between 0.9- 
1.1 GDP in the European Union. For this reason, non-cash payment instruments are an important element of the dynamically developing e-business which covers all business processes carried out electronically or with significant support of ICT solutions, including non-cash transactions.

The development of cryptocurrencies is particularly dynamic, despite the lack of precise and exhaustive regulations related to the use of this means of payment. The issuance of cryptocurrencies is also complicated due to problems related to the absence of a uniform definition of this form of money and inability to clearly differentiate it from other non-cash means of payment. Hence, in the literature on the subject one can find a number of terms whose common feature is the concept of cryptography. These terms indicate that cryptocurrencies are distributed accounting systems, based on cryptography, which allow for storing information on the account holder's status in contractual units. Others state that it is a limited or virtual currency with a limited amount of circulation that uses cryptographic solutions to ensure security of transactions, beyond the control of the central authorities, and thus immune to intervention or manipulation by governments. One can also find definitions stating that a cryptocurrency is an innovative, distributed accounting system whose key element is the Blockchain. This chain is an encoded cryptographic structure operating without the participation of intermediary institutions responsible for the verification of transaction data and responsible for storing accounting entries, payments or transactions of system participants. It can also be defined as a kind of decentralized and distributed database operating on the Internet, based on a peer-to-peer (P2P) architecture and not having a centralized data storage location.

The adopted cryptocurrency concept sets out its numerous advantages (although often the advantage for some may be perceived as a disadvantage to others) such as for instance: increased resistance to cyberattacks, anonymity, independence, being out of control and supervision of domestic and international financial institutions. It should be clearly emphasized that, although the first application of Blockchain technology was related to the cryptocurrency Bitcoin, nowadays this technology is used, among others, in the Internet of Things (IoT) or in Distributed Ledger Technology. The consequence of the above is the visible increase in the capitalization of the crypto market in the world. This is favored by the dynamic development of new technologies, strong money virtualization trend, and a partial loss of social trust in the current monetary system.

Out of over 1334 cryptocurrencies that exist nowadays, Bitcoin is perhaps the most recognizable on the global market. It emerged as a manifestation of opposition to the banking system, financial institutions and governments who had been responsible for the crisis on global markets in 2007-2009. In the literature on the subject, Bitcoin is defined as e.g. a payment and investment instrument, expressed in the form of electronic records, operating in virtual space, or a decentralized, selected by the market internet currency operating on the basis of cryptography and using P2P network technologies. There is also a definition that Bitcoin is a virtual money, composed of a sequence of zeros and ones stored on computer disks. These definitions emphasize the immaterial character of cryptocurrencies and the scope of their functioning limited only to the Internet. This innovative distributed transaction system uses a peer-to-peer network communication model, and data "portfolios" located on users' computers or on external websites (in the form of specialized applications e.g. Blockchain.info and Quandl.com).

Against this background, however, arises a problem regarding the way of interpreting cryptocurrencies such as Bitcoin. It is vital to determine its role in e-business as a medium of exchange, payment and value measure, and to provide answer to the final question whether Bitcoin should really be considered money. To answer this question it is necessary to turn to the definition of traditional money which says that money is a widely accepted commodity by means of which it is possible to determine the economic value of purchased goods and services and make payments. Other definitions indicate, that it is an asset that stores purchasing power or that it is an asset with high liquidity and predictable value. Still, other authors emphasize that it is a means of linking the present with the future, or everything that is commonly accepted as a payment for goods, services and repayment of debt. From the point of view of economic theory, money is a rare commodity that is traded on financial markets. It is also a legally defined payment instrument associated with a real social product that can be both material and non-material and used to express, store and transfer values.

Contemporary money can be defined, among others through its functions and properties. The classic functions of money include: a value measure (a means of expressing value), a unit of account (register), a legal tender (a means of transferring value), a medium of exchange (rotational), a means of storing values (thesaurization). The literature also emphasizes that money is characterized by widespread acceptability, divisibility to smaller units and difficulty to falsify. The first function of money - a measure of the value of goods and services - refers to the price category, which is the value of the goods expressed in cash. Money issuers perform the function of guarantors of its stability through the pursuit of monetary policy, and the amount of currency held is equivalent to the number of "owned shares" in all goods produced in a given economy. Bitcoin as a cryptocurrency has no value, but it only has a rate against traditional currencies, which can be influenced by many factors, including decisions of politicians or state authorities (as was the case with MT Gox). Thus, the function of the value meter is not fully implemented by Bitcoin and is significantly different from traditional money. One of the functionalities, which is an important value for Bitcoin users, is the possibility of making anonymous cheap online transfers, verified instantly, by means of a global network and a peer-to-peer model. However, a limited number of Bitcoin units may lead (and leads) to an increase in the exchange rate and deflation of prices expressed in Bitcoin and may also increase its susceptibility to speculative attacks and price fluctuations, Figure 2. 


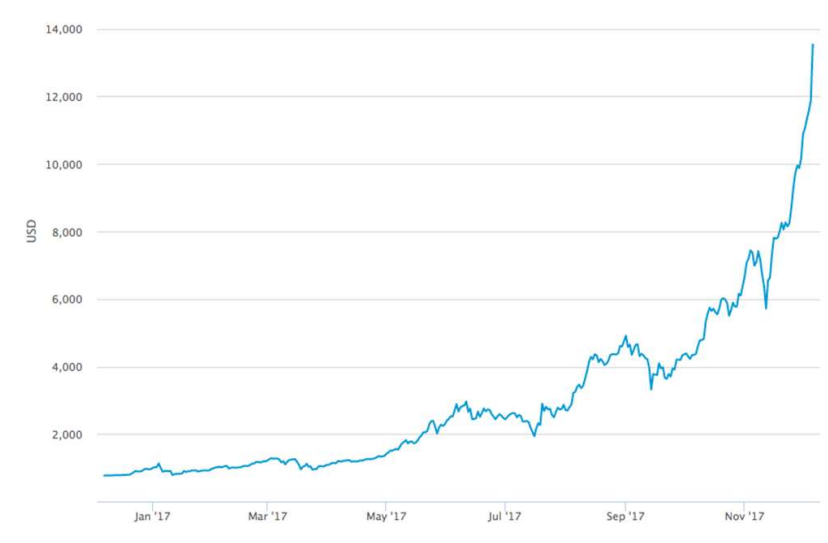

FIGURE 2. AVERAGE USD MARKET PRICE BASED ON (BLOCKCHAIN.INFO, 2018)

Thus, the function of Bitcoin as a means of payment seems to be highly limited. Lack of features convergent with traditional money, is also shown when one wants to use Bitcoin as a means of storing value. Bitcoin in itself has no value, it only includes a speculative price of itself. Taking into account the above, it can be stated that it is not possible to assign Bitcoin the thesaurization function.

On the other hand, Bitcoin can perform the function of a medium of exchange because it is acquired for the purposes of exchange for consumer or production goods. It is also true to say that it is a rare good due to the algorithmically limited number of units in circulation up to the volume of 21 million, Figure 3.

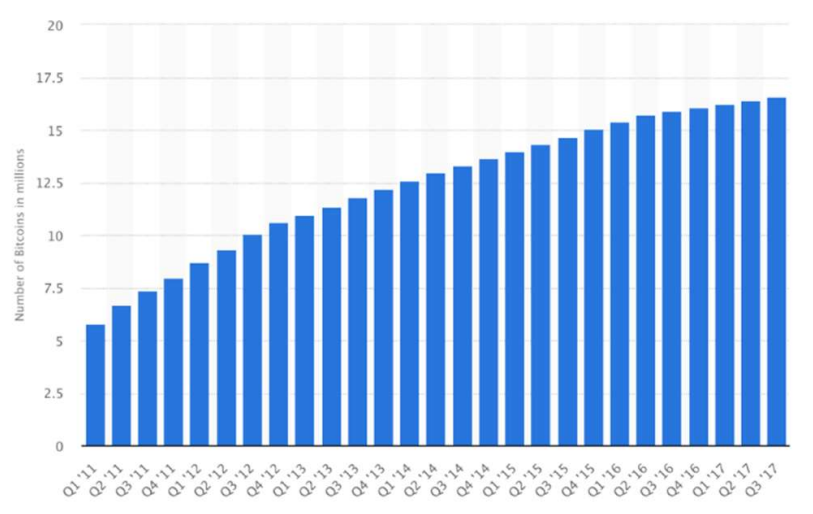

FiguRE 3. SUPPLY OF BITCOIN CRYPTOCURRENCIES IN Q1.2011 - Q3.2017. STATUS ON Q3.2017 - 16.6 MILLION UNITS (STATISTA, 2018)

It is also possible to assign to Bitcoin the easy transfer feature via the extensive Blockchain network and ATM devices (bitomats that enable Bitcoin cryptocurrency to be purchased), divisibility into smaller units through which transactions in the network are carried out, and acceptability among Bitcoin system users. It seems controversial however, to attribute it to the universality of acceptance as the system is used by a relatively small number of users. Moreover, goods purchased using Bitcoin can also be purchased with other currencies, Figure 4.

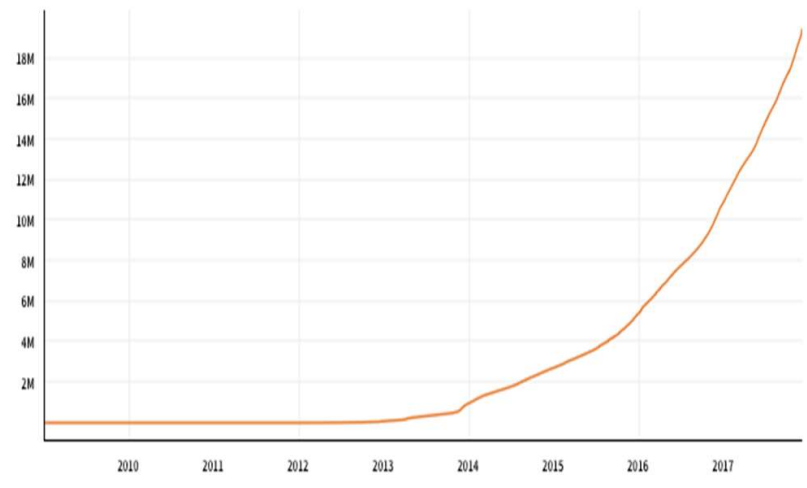

Figure 4. NUMBER OF BITCOIN WALLET HOLDERS (QUANDL.COM,2017)

The daily number of Bitcoin transactions i.e. 346,283 (as at $02 / 12 / 201722: 24: 42$ ) as well as the number of devices in the world accepting Bitcoin (1,587 items), seem to be relatively small (the number of traditional ATMs located only in Poland is 23,528 - Q2 2017 according to the nbp.pl portal). It should be noted, however, that a dynamic upward trend here can be observed, Figure 5.

Bitcoin also seems to be doubtful as a standard investment value. In case of acquisition of standard investment securities, the investor maintains certain guarantees in the event of a decrease in their price (e.g. the possibility to wait for maturity of the debt in case of bonds). Whereas, investing in Bitcoin is more of a gambling and is similar to investing in futures without a lower price limit.

Based on the above analysis, it can be argued that the Bitcoin cryptocurrency does not fulfill all the functions of traditional money and should not be considered as such. Bitcoin should also not be considered as electronic money, despite showing large similarities to this means of payment. The justification for the above thesis is to be found, among others, in the provisions of article 2 point 2 of the Directive 2009/110 / EC of the European Parliament and of the Council of 16 September 2009 on the taking up and pursuit of electronic money institutions and supervision over their activities, as well as in the provisions of article 2 (21a) of the Polish Act on Payment Services. The first document indicates that "electronic money" carries monetary value stored electronically, including magnetically, constituting the right to a claim against the issuer, which is issued in exchange for cash in order to perform payment transactions specified in article 4 point 5 of Directive 2007/64 / EC and accepted by natural or legal persons other than the issuer of electronic money. The Directive also indicates a closed catalog of entities entitled to issue electronic money: credit institutions (Article 4 point 1 of Directive 2006/48/EC), electronic money institutions, postal giro institutions (if they are entitled to issue electronic money in accordance with the domestic law), national central banks and the European Central Bank if their role does not constitute them as monetary authorities or other public bodies, Member States or their bodies, if they do not act as public bodies. The second document (the reference to the Polish market results from the author's research on cryptocurrencies on this specific market), indicates 
that it is a monetary value stored electronically, including magnetically, issued, with the obligation to buy it, for the purpose of making payment transactions, accepted by entities other than the electronic money publisher only. As regards the Polish market, issuance of electronic money requires obtaining permit from the financial supervisory authority - the Supervisory Commission.

Bitcoin in opposition to electronic money and traditional fiat currency, has no single issuer. It remains outside the direct control of central financial institutions and functions without adequate economic support. Units of this cryptocurrency are created by the system automatically, in a manner planned in advance by the system's creators, based on emission assumptions inscribed in the source code of cryptocurrencies. As a result of these activities, the number of Bitcoins in circulation is a function of the nominal value of transactions performed and the said rigid limitation of the number of units in circulation (the Bitcoin emission control mechanism assumes that their number in circulation cannot exceed 21 million units). It should be noted that standard currencies are manually controlled, which allows them to maintain their relative stability in the face of changing market situation. Bitcoin, on the other hand, being automatically controlled, seems to be less resistant to market shocks. The above allows to state that the Bitcoin cryptocurrency does not meet both the provisions of Directive 2009/110/EC and the provisions of the Polish Act on Payment Services, defining electronic money.

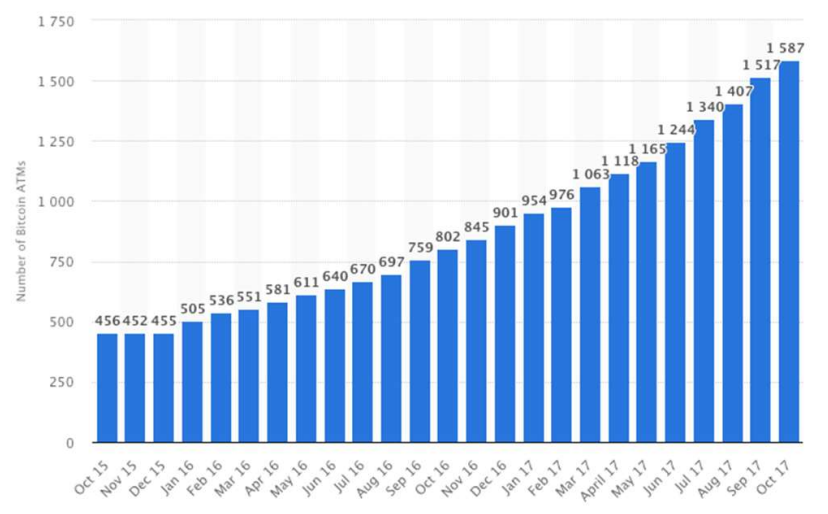

FigURE 5. THE NUMBER OF BITCOIN ATM DEVICES IN THE WORLD IN THE YEARS 2015-2017 (STATISTA, 2018)

\section{III.RISK OF INVESTMENT IN BITCOIN}

As indicated earlier, it seems that Bitcoin has no standard investment value. Investments in Bitcoin are often referred to as a particular type of gambling and resemble investments in futures without a lower price limit. To assess the risk of investment in Bitcoin, it is necessary to use the risk measure. The problem of measurement and monitoring of investment risk (including financial investments) is one of the greatest challenges of modern economics. The literature on the subject refers to the above issues through volatility measures (variance of rate of return, standard deviation of the rate of return, coefficient of variation of the rate of return), measures of sensitivity (beta coefficient, duration of investment) or measures of risk (semi-refund of rate of return, standard semierror rate of return, Value at Risk).

According to Markovitz, the risk measure of the investment portfolio is the variance of the return on the investment portfolio. The imperfection of the method (as the variance of the rate of return included both surpluses over the expected value and decreases below the expected value measured in squares) was adjusted by the so-called semivariance. However, this correction led to the loss of the analytical form of the solution proposed by Markowitz. The Basel Committee on Banking Supervision in 2006, recommended the use of the socalled Value at Risk (VaR) measure. Originally, VaR was only used as an internal measure used to estimate risk in banks (as a method of assessing market risk, it was introduced through an amendment to the Basel II contract).

Here, however, arises the problem of possibility to increase the degree of risk exposure (VaR may increase) generated by the portfolio of assets, with its diversification. The VaR measure is the amount an investor may lose (value of losses) as a result of investing in the portfolio with the assumed time horizon and confidence level. It is also admissible that this is the value of losses that may be exceeded with probability $\alpha$ or a loss value, which with probability equal to $(1-\alpha)$ may not be exceeded on the following day. Summing up, the VaR method allows obtaining information on the general risk level regardless of the type of assets analyzed. The following conclusions emerge from the VaR method:

- when a given asset brings higher profits, with a lower level of VaR risk, it should have been increased,

- when a given asset brings higher profits with the same level of $\mathrm{VaR}$ risk, the involvement in this asset should have been increased.

Value at risk VaR can be considered in absolute terms (through the current value of capital employed in the investment) as well as in relative terms (through the expected value of capital employed in the investment). Probability allows us to predict, estimate unknown results based on known parameters, while the credibility allows us to estimate the unknown parameters based on known results.

For the needs of the present paper, the risk of investments in Bitcoin was compared on selected world exchanges (Bitfinex, GDAX, Bitstamp, BTCC, Gemini) and the risk of investing in selected "traditional" currencies - USD, AUD, CAD, EUR, HUF, CHF, GBP (exchange rate in relation to PLN in the period $01 / 01 / 2009$ - 10/12/2017). The choice resulted from the 24 Hour Volume Rankings - Currency. The VaR measure was adopted in relative terms, understood as the maximum value that an investor would like to lose as a result of an investment, for a given period of time, with the assumed tolerance level, (1).

$$
\begin{aligned}
& P\left(W \leq\left(E(W)-V a R_{R}\right)=\alpha\right. \\
& P\left(W>\left(E(W)-V a R_{R}\right)=1-\alpha\right. \\
& \operatorname{VaR}_{R}=E(W)-W_{\propto} \\
& \operatorname{VaR}_{R}=W_{0}\left(1+(E(r))-W_{0}\left(1+r_{\alpha}\right)\right. \\
& \operatorname{VaR}_{R}=W_{0} E(r)-W_{0} r_{\propto}=W_{0}\left(E(r)-r_{\alpha}\right) \\
& \quad=-W_{0}\left(r_{\propto}-E(r)\right) \\
& \quad \text { where: } \quad
\end{aligned}
$$

$\alpha$ - accepted tolerance $(0,05$ or 0,01$)$ 
In the calculation of value-at-risk, the method of historical simulation was used, which focuses on the statistical analysis of the empirical distribution of return rates. In addition, this method allows for better mapping of market behavior. It should be noted, that distribution of returns on the analyzed exchanges did not have the characteristics of normal distributions.

An assumption regarding the normality of the distribution of rates of return was also adopted. This assumption may be encountered in many areas of finance and valuation models (e.g. the Black-Scholes option valuation model), forecasts (e.g. using the National Science Committee), risk assessment or verification of economic theories. It allows to calculate the probability of gain or loss from a given investment or Value at Risk (VaR). The adoption of the above assumption results directly from the central limit theorem, indicating that the use of a normal distribution is permissible for each continuous random variable, subject to the independence of individual variable values, the origin of observations from the same distribution and their sufficiently large number - min. 30 (the assumption was fulfilled in the conducted study).

The author analyzed the time series of Bitcoin returns on selected exchanges. As expected, the results obtained confirmed that time series are burdened with high kurtosis (leptokurtic distribution) and skewness. The results of chisquare tests also confirmed the need to reject the null hypothesis about the normality of rates of return for 0.05 and 0.01 confidence levels. Thus, it was confirmed that the rates of return from Bitcoin do not have a normal distribution. Histogram of daily Bitcoin returns on the Bitfinex stock market is shown in Figure 6.

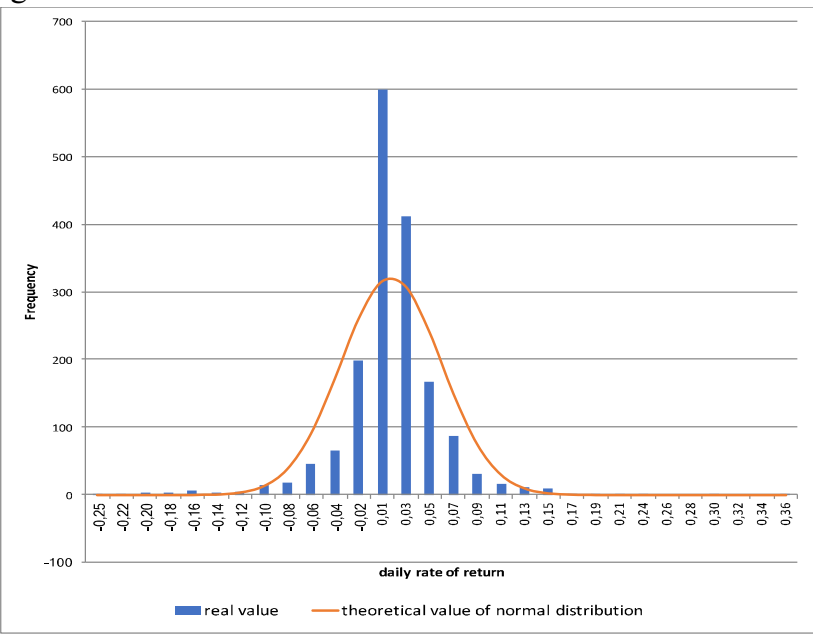

FigURE 6. HISTOGRAM OF DAILY RETURNS ON THE BITFINEX STOCK MARKET - SELECTION BASED ON THE CAPITALIZATION VALUE ON THE DAY 15.12.2017 (1706 QUOTATIONS IN THE PERIOD 2013-2017) (COINMARKETCAP.COM, 2018)

The results of the Value at Risk (VaR) calculations together with their percentage change for 0.05 and 0.01 confidence levels are presented in Table 1.
TABLE 1. INVESTMENT RISK FOR SELECTED EXCHANGES AND CONFIDENCE LEVELS WITH A PERIOD OF 10 DAYS (COINMARKETCAP.COM, 2018)

\begin{tabular}{|c|c|c|c|c|c|}
\hline Trade & Volume & $\begin{array}{c}\text { VaR(0,05 } \\
\mathbf{n}\end{array}$ & $\begin{array}{c}\text { Change } \\
(\%)\end{array}$ & $\begin{array}{c}\text { VaR(0,01 } \\
\mathbf{( \% )}\end{array}$ & $\begin{array}{c}\text { Change } \\
(\%)\end{array}$ \\
\hline Bitfinex & $\begin{array}{c}\$ 479028 \\
000,00\end{array}$ & $\begin{array}{c}\$ 109332 \\
053,49\end{array}$ & $-22,82 \%$ & $\begin{array}{c}\$ 154593 \\
529,73\end{array}$ & $-32,27 \%$ \\
\hline Gemini & $\begin{array}{c}\$ 961225 \\
00,00\end{array}$ & $\begin{array}{c}\$ 220038 \\
14,72\end{array}$ & $-22,89 \%$ & $\begin{array}{c}\$ 311129 \\
92,73\end{array}$ & $-32,37 \%$ \\
\hline BTCC & $\begin{array}{c}\$ 294397 \\
000,00\end{array}$ & $\begin{array}{c}\$ 673916 \\
82,93\end{array}$ & $-22,89 \%$ & $\begin{array}{c}\$ 952906 \\
10,63\end{array}$ & $-32,37 \%$ \\
\hline Bitstamp & $\begin{array}{c}\$ 117389 \\
000,00\end{array}$ & $\begin{array}{c}\$ 268720 \\
20,66\end{array}$ & $-22,89 \%$ & $\begin{array}{c}\$ 379965 \\
47,15\end{array}$ & $-32,37 \%$ \\
\hline GDAX & $\begin{array}{c}\$ 209344 \\
000,00\end{array}$ & $\begin{array}{c}\$ 479218 \\
35,04\end{array}$ & $-22,89 \%$ & $\begin{array}{c}\$ 677606 \\
00,80\end{array}$ & $-32,37 \%$ \\
\hline
\end{tabular}

The analysis of tabular data indicates that investments in Bitcoin are subject to high risk, which may lead to a reduction of the initial capital value by about $21 \%$ for the 0.05 confidence level and about $32 \%$ for the 0.01 confidence level (in the 10th day). In addition, there was a negligible correlation of the Bitcoin return rate in relation to the number of Bitcoins remaining in circulation, quarterly (for Bitfinex, it is 0.277771642 ), Figure 7.

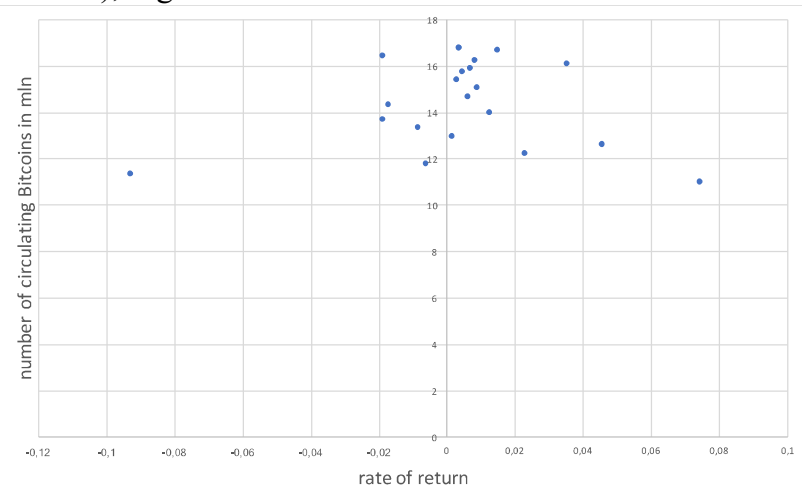

FIGURE 7. CORRELATION OF THE RATE OF RETURN FROM BITCOIN IN RELATION TO THE NUMBER OF BITCOINS IN CIRCULATION FOR THE BITFINEX STOCK EXCHANGE (STATISTA, 2018)

Similar analyzes were performed for selected currency pairs, performing an average of 250 observations/year - which resulted in a total of 2275 observations for each currency during the study period. It was also assumed that the average change for one day is zero, which for a portfolio of one asset may be expressed as (2).

where:

$$
\boldsymbol{V a R}=\boldsymbol{W} \times \boldsymbol{\sigma} \times \boldsymbol{k}
$$

$W$-value of the portfolio on the previous day (in the previous period),

$\sigma$-standard deviation of the price of the asset,

$k$ - number of standard deviations below average (following values was assumed - for the confidence level $c=0.95$ the $k=-1.645$ and for the confidence level $c=0,01$ the $k=-2.326)$.

It should be highlighted that VaR value of the portfolio 
consisting of a single asset (such a simplifying assumption was assumed) is a function of the portfolio value, asset price volatility, tolerance level and time horizon.

As in the case of exchanges, the analysis of the time series of the return rates of the currencies examined showed that the time series significantly differ from the normal distribution - they are burdened with high kurtosis (4.303 for USD - leptokurtic distribution) and skewness (0.1333 for USD). The results of chi-square tests also pointed to the necessity of rejecting the null hypothesis on the normality of rates of return for 0.05 and 0.01 confidence levels. Thus, the time series of the rates of return for the examined currencies do not have a normal distribution, Figure 8.

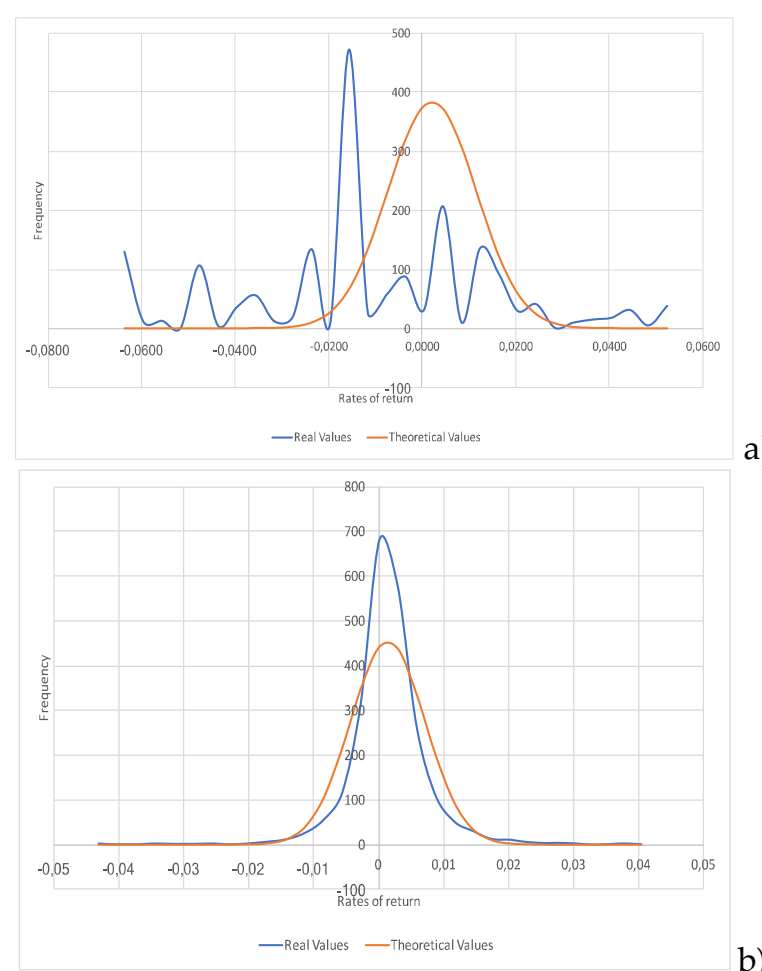

Figure 8. Histogram of daily rates of return for USD (a) and EUR (b) respectively (2,275 listings in the period 2013-2017) (Coinmarketcap.com, 2018)

The results of the value-at-risk calculations - VaR for the amount of 100 million units together with the percentage change in its value for 0.05 and 0.01 confidence levels are presented in Table 2.

The results of VaR analysis for selected currency pairs unambiguously indicate that investments in Bitcoin are burdened with much higher risk (about 5 times higher for the 0.05 confidence level and 6 times higher for the 0.01 confidence level).
TABLE 2. INVESTMENT RISK IN TRADITIONAL CURRENCIES EXPRESSED IN TERMS OF VALUE AT RISK IN RELATIVE TERMS OVER A PERIOD OF 10 DAYS

\begin{tabular}{|c|c|c|}
\hline Trade & $\begin{array}{c}\text { Change (\%) for } \\
\text { VaR }(0,05)\end{array}$ & $\begin{array}{c}\text { Change (\%) for VaR } \\
(0,01)\end{array}$ \\
\hline USD/PLN & $-4,88 \%$ & $-6,90 \%$ \\
\hline AUD/PLN & $-3,82 \%$ & $-5,40 \%$ \\
\hline CAD/PLN & $-4,06 \%$ & $-5,74 \%$ \\
\hline EUR/PLN & $-2,97 \%$ & $-4,20 \%$ \\
\hline 100 HUF/PLN & $-2,54 \%$ & $-3,59 \%$ \\
\hline CHF/PLN & $-4,46 \%$ & $-6,31 \%$ \\
\hline GBP/PLN & $-4,09 \%$ & $-5,78 \%$ \\
\hline
\end{tabular}

\section{DISCUSSION}

The examination conducted by the author clearly indicates the complex nature of cryptocurrencies. This complexity concerns both definition and legislative issues as well as issues related to trading aspects. Despite the growing popularity of cryptocurrencies, many countries do not sanction this means of payment, paying attention to its speculative nature.

However, it is difficult to state clearly that cryptocurrencies will cease to be an element of e-business complexity solution. Similar doubts existed with respect to electronic money which now for good fits into the financial instruments of the eeconomy. The considerations presented by the author seem to confirm the thesis of speculative character of cryptocurrencies. The high volatility of the cryptocurrencies value, its sensitivity to political decisions, the lack of centralized supervision, no or very limited legal regulations regarding this instrument makes this instrument a high-risk instrument.

Notwithstanding, the future of cryptocurrencies will be verified by the market itself, by the users of this form of the payment and by the investors who will or will not decide to put their money in it.

\section{CONCLUSIONS}

The growing interest in cryptocurrencies results from many reasons e.g. transaction anonymity, relatively low risk of losing funds, speed of transaction execution, lack of or small commissions on transactions performed, independence from governments and banking systems. It is also the manifestation of the loss of trust in the current monetary system and financial institutions. It should be emphasized that despite the growing popularity of cryptocurrencies and the often-encountered equating them to money - especially electronic money, cryptocurrencies do not fulfil the definition of both electronic money or money in general. The future of Bitcoin is not yet decided however, it may become the money of the future on its own rights. For the moment though, due to the lack of its value in use (it is empty money) and dependence on complementary capital goods, it is relatively unlikely to obtain a money titer. In many countries, there is currently a discussion about changes in the legislative system and some financial operations with the 
use of cryptocurrencies (e.g. banking law or tax law) are under way. Regardless of the pace of changes in the banking and fiscal systems related to cryptocurrencies, it should be clearly stated that non-cash payment instruments are of significant importance for reducing the costs of cash transactions and further development of e-business. The dynamic development of cryptocurrencies and their increasing popularity as a means of payment in many areas of socio-economic activity (cafes, universities, stock exchanges, etc.) shows that it cannot remain unnoticed and legally unspecified in the contemporary ebusiness.

\section{REFERENCES}

Blockchain.info. (2018). Bitcoin Block Explorer - Blockchain. [online] Available at: http://blockchain.info [Accessed 4 Mar. 2018].

Coinmarketcap.com. (2018). All Cryptocurrencies | CoinMarketCap. [online] Available at: https://coinmarketcap.com/all/views/all/ [Accessed 4 Mar. 2018].

Duwendag, D., Ketterer, K., Kosters, W., Pohl, R. and Simmert, D. (1995). Teoria pieniądza i polityka pieniężna. Warszawa: Poltext.

Forecast Alert: IT Spending, Worldwide, 2Q15 update. Gartner, Inc. and/or its Affiliates, Gartner, Inc. and/or its Affiliates, 2015.

$\begin{array}{lrrr}\text { Coinmarketcap.com. (2018). } 24 \text { Hour Volume Rankings (Exchange) | } \\ \text { CoinMarketCap. } & \text { [online] } & \text { Available }\end{array}$ CoinMarketCap.
https://coinmarketcap.com/exchanges/volume/24-hour/ [Accessed 4 Mar. 2018].

Coinmarketcap.com. (2018). Top 100 Cryptocurrencies by Market Capitalization. [online] Available at: https://coinmarketcap.com/currencies/ bitcoin/\#markets [Accessed 4 Mar. 2018].

Investopedia. (n.d.). [online] Available at: http://www.investopedia.com/terms/ c/cryptocurrency.asp [Accessed 4 Mar. 2018].

Keynes, J. (1956). Ogólna teoria zatrudnienia, procentu i pieniądza. Warszawa: PWN.

Kliestik, T., Musa, H. and Frajtová-Michalikova, K. (2015). Parametric methods for estimating the level of risk in finance. Procedia-Economics and finance, 24, pp.322-330.

Kurek, R. (2015). Bitcoin a ekonomiczne funkcje pieniądza. Prace naukowe Uniwersytetu Ekonomicznego we Wrocławiu, 395.

Marchewka, K. (2001). Funkcje pieniądza a funkcje kapitałów (oszczędności) pieniężnych. Poznań: Ruch prawniczy, ekonomiczny i socjologiczny, p.193.

Michalik, Ł. (2012). Bitcoin - waluta wolnych ludzi czy pomysłowa piramida finansowa?. Gadżetomania.

Mieses, L. (2007). Ludzkie działanie. Warszawa: Instytut Ludwiga von Misesa.

Statista. (2018). Number of Bitcoins quarterly 2018 | Statistic. [online] Available at: https:/www.statista.com/statistics/247280/number-of-bitcoinsin-circulation/ [Accessed 4 Mar. 2018].

Mishkin, F. (2002). Ekonomika pieniądza, bankowości i rynków finansowych. Warszawa: PWN

Nbp.pl. (2018). Narodowy Bank Polski - Internetowy Serwis Informacyjny. [online] Available at: http://nbp.pl [Accessed 17 Oct. 2018].

Piaszczyński, W. (2004). Anatomia pieniądza. Warszawa: "Script."

Piotrowska, A. (2014). Bitcoin a definicja i funkcje pieniądza. Annales Universitatis Mariae Curie-Skłodowska, XLVIII(3).

Quandl.com. (2018). Quandl. [online] Available at: https://www.quandl.com/data/BCHAIN/MWNUS-Bitcoin-My-WalletNumber-of-Users [Accessed 17 Oct. 2018].
Quandl.com. (2018). Quandl. [online] Available at: HTTPS://WWW.QUANDL.COM/DATA/BCHAIN/MWNUS-BITCOINMY-WALLET-NUMBER-OF-USERS [Accessed 02 Dec. 2017]

Sieroń, A. (2003). Czym jest Bitcoin. Ekonomia, Wroclaw Economic Review, 19(4)

Stępień, A. (2000). Atrakcyjność wirtualnej gospodarki. In: Zarządzanie organizacjami gospodarczymi $w$ warunkach globalizacji. Łódź: Politechnika Łódzka, p.328.

Waszczuk, P. and Service, I. (2018). Gartner: Budżety na IT mniejsze o 4,7 proc.. [online] Computerworld.pl. Available at: http://www.computerworld.pl/news/346414/Gartner.Budzety.na. IT.mniejsze.o.4.7. proc.html [Accessed 4 Mar. 2018]. 